\title{
43. QUATERNARY ISOTOPE STRATIGRAPHY OF HOLE 593, CHALLENGER PLATEAU, SOUTH TASMAN SEA: PRELIMINARY OBSERVATIONS BASED ON FORAMINIFERS AND CALCAREOUS NANNOFOSSILS ${ }^{1}$
}

\author{
Campbell S. Nelson and Chris H. Hendy, University of Waikato \\ and \\ Walter C. Dudley, University of Hawaii at Hilo²
}

\begin{abstract}
A moderate-resolution isotope stratigraphy (with an average of one sample per 17,500 yr.) derived from the benthic foraminifer Uvigerina (or Cibicides), the planktonic foraminifer Globigerina bulloides, and calcareous nannofossil concentrates is presented for the entire Quaternary (and latest Pliocene) section of mid-upper bathyal calcareous oozes from DSDP Site 593, western Challenger Plateau, south Tasman Sea. Superimposed on a trend of gradually increasing average $\delta^{18} \mathrm{O}$ values through the Pleistocene, reflecting the progressive buildup of polar ice sheets, is a record of highfrequency but generally low amplitude $(0.5-1 \%$ ) isotope fluctuations in the early Quaternary (1.9-1.0 m.y.), followed by a greatly increased intensity $(1.5-2.0 \%$ of glacial-interglacial fluctuations during the late Quaternary $(<1.0 \mathrm{~m} . \mathrm{y}$.$) .$ The standard late Quaternary isotope stages 1 to 24 are mainly resolvable. Significant excursions in both $\delta^{18} \mathrm{O}$ and $\delta^{13} \mathrm{C}$ values at various times during the Quaternary are suggested to be due to periodic, fundamental changes in ocean circulation properties over the plateau. For example, intensified upwelling of Antarctic Intermediate Waters during several glacial periods is indicated by the convergence of benthic and planktonic foraminiferal $\delta^{18} \mathrm{O}$ data, and productivity variations may account for certain $\delta^{13} \mathrm{C}$ spikes in the record. With increasingly higher resolution analysis this core will provide a useful Quaternary isotope reference section for southern temperate waters in the southwest Pacific, centered on New Zealand.
\end{abstract}

\section{INTRODUCTION}

Studies of the stable isotope composition of planktonic and benthic foraminifers, and more recently calcareous nannofossils, have become essential tools for paleoceanographic and paleoclimatic studies and in marine stratigraphic correlation (Kennett, 1982, 1983). The oxygen isotope record contains information on changes in ocean temperature and salinity, and especially on the isotope composition of ocean water as it relates to the extent of continental glaciations, thereby providing a stratigraphic link between on-land sequences and events in the oceans. Carbon isotope data can indicate changes in circulation patterns, productivity, and global carbon budget. Data from different organisms inhabiting specific depth ranges (i.e., coccolithophores, planktonic foraminifers, and benthic foraminifers) should ultimately permit reconstruction of stratification and circulation patterns of ancient oceans and elucidate the evolution of modern circulation patterns.

Detailed stable isotope stratigraphies of the Quaternary are available for much of the Atlantic and parts of the Indian and Pacific oceans (Emiliani and Flint, 1963; Emiliani, 1971; Shackleton and Opdyke, 1976; Prell, 1982; Shackleton et al., 1983; Imbrie et al., in press; Shackleton et al., 1984), but no high-resolution Quaternary isotope data are currently available for the south-

\footnotetext{
${ }^{1}$ Kennett, J. P., von der Borch, C. C., et al., Init. Repts. DSDP, 90: Washington (U.S. Govt, Printing Office).

2 Addresses: (Nelson) Department of Earth Sciences, University of Waikato, Hamilton, New Zealand; (Hendy) Department of Chemistry, University of Waikato, Hamilton, New Zealand; (Dudley) Natural Sciences Division, University of Hawaii at Hilo, Hilo, Hawaii 96720 .
}

west Pacific region. The area is ideal for isotope studies since every major surface water mass between equatorial and subantarctic latitudes is present over a relatively short traverse, and these water masses are underlain by shallow-water $(<2000 \mathrm{~m})$ pedestals with rich calcareous sequences, mainly uncomplicated by dissolution and turbidite input. DSDP Leg 90 drilled these sequences at nine sites (Fig. 1) using the recently developed hydraulic piston corer, which provided both excellent quality cores and high sediment recovery rates of $\sim 90 \%$, prerequisites for high-resolution stratigraphic work.

This chapter reports preliminary isotope results for the Quaternary oozes at cool subtropical (temperate) Site 593. It is proposed ultimately to investigate the Quaternary isotope record at several of the other sites on Leg 90 to obtain an "isotope traverse" for subantarctic to equatorial latitudes. Work is in progress on the subantarctic (Site 594) cores (Nelson, Hendy, Cuthbertson, et al., this volume). These two southern sites (593 and 594) should be particularly useful as stable isotope reference sections against which on-land Quaternary sequences in Australasia, and especially those in New Zealand (Suggate et al., 1978), can be compared and more reliably correlated.

\section{PREVIOUS WORK}

Isotope analyses of earlier DSDP core samples from the southwest Pacific area have provided important information on general paleoclimate trends and the history of development of the Antarctic ice sheet through the Cenozoic (Shackleton and Kennett, 1975a, 1975b; Kennett and Shackleton, 1976; Kennett et al., 1979). Two of these studies (Shackleton and Kennett, 1975a; Kennett 
et al., 1979) dealt specifically with the late Cenozoic isotope history at DSDP Site 284, located close to present Site 593. Their principal result demonstrated three conspicuous episodes of cooling: in the latest Miocene (5.26.2 m.y. ago, Loutit and Kennett, 1979) associated with major expansion of Antarctic ice sheet; briefly in the middle Pliocene ( $\sim 3.5$ m.y. ago); and again in the late Pliocene ( $\sim 2.6$ m.y. ago), associated with the initiation of Northern Hemisphere glaciation. Emphasis in these papers was clearly directed at the late Tertiary core interval, and only eight sample points from the Quaternary section provided evidence of glacial oscillations (Kennett et al., 1979).

\section{SETTING AND QUATERNARY CORE CHARACTERISTICS AT SITE 593}

\section{Modern Oceanographic Setting}

Site $593\left(40^{\circ} 30.47^{\prime} \mathrm{S} ; 167^{\circ} 40.47^{\prime} \mathrm{E}\right)$ is located in 1068 $\mathrm{m}$ of water near the western margin of Challenger Plateau, $270 \mathrm{~km}$ from the nearest land mass of northern South Island, New Zealand (Fig. 1). The site is a reoccupation of Site 284 cored during DSDP Leg 29 (Kennett, Houtz, et al., 1975). It is located some $400 \mathrm{~km}$ north of the present-day position of the subtropical convergence in the cool subtropical (temperate) water mass lying midway between true subtropical water masses north of New Zealand and subantarctic waters to the south (Knox, 1970).

Some properties of the water mass structure in the southern Tasman Sea are schematically illustrated in Figure 2. Surface circulation in the vicinity of Site 593 is dominated by the generally northeast-moving Tasman Current. The Current results from interaction of the Subantarctic Surface Water of the West Wind Drift with a complex system of anticyclonic eddies forming off southeastern Australia and fed by the subtropically derived East Australian Current (Stanton, 1973). Biological measurements of near-surface waters over Challenger Plateau show that present-day productivity in the vicinity of Site 593 is generally over twice that of the surrounding waters (Bradford and Roberts, 1978), possibly associated with topographic upwelling along the western edge of the Plateau and in Bellona Gap. The seafloor at Site 593 is presently under the influence of Antarctic Intermediate Water, with low salinity $(\sim 34.5 \%)$ and a temperature of $4-5^{\circ} \mathrm{C}$.

\section{Lithology and Age}

The uppermost six cores from Hole 593 (0-53.1 m sub-bottom depth) recovered Quaternary (Zones NN21NN19a) through latest Pliocene (top Zone NN16) foraminifer-bearing $(5-25 \%)$ to foraminifer $(25-50 \%)$ nannofossil ooze.

Age control for the section (Fig. 3) is provided by both biostratigraphy and paleomagnetic stratigraphy (Site 593 report, this volume). Figure 3 includes a preferred (Curve A) and an alternative but less likely (Curve B), age interpretation for the sequence. At nearby Site 284, drilled on DSDP Leg 29, a middle Pleistocene disconformity was inferred to occur at $\sim 9 \mathrm{~m}$ sub-bottom depth
(Kennett, Houtz, et al., 1975; Kennett and Vella, 1975; Kennett et al., 1979). Hornibrook (1982) and A. R. Edwards (pers. comm. 1984) have subsequently discounted the evidence for such a hiatus. At Site 593 the shipboard micropaleontologic and lithologic data suggest that no major unconformities occur in the Quaternary sequence, although the Olduvai Subchron (1.66-1.88 m.y.) paleomagnetic event was at first not resolved (Site 593 site chapter, this volume); however, Barton and Bloemendal (this volume) have subsequently recognized an Olduvai interval from about 32-36 m sub-bottom depth. Based on the last occurrence of the nannofossil Discoaster brouweri the Plio/Pleistocene boundary is placed near the top of Core 593-6, at $43.9 \mathrm{~m}$ sub-bottom depth, giving an average sedimentation rate for the Quaternary of 23 m/m.y. (Fig. 3, Curve A).

A problem concerns the age of $1.45 \mathrm{~m} . \mathrm{y}$. for the last occurrence of the nannofossil Calcidiscus macintyrei at $17.74 \mathrm{~m}$ sub-bottom depth (Lohman, this volume). The date is inconsistent with the paleomagnetic age of about 0.75 m.y. at this level. If, in fact, the Jaramillo Subchron was replaced by the initially unresolved Olduvai Subchron, then the $C$. macintyrei age remains tenable, but necessitates a major ( $0.7 \mathrm{~m}$.y.) disconformity at about $17 \mathrm{~m}$ sub-bottom depth (Fig. 3). This is unlikely for several reasons. In particular, it would demand impossibly high sedimentation rates $(1035 \mathrm{~m} / \mathrm{m} . \mathrm{y}$.) from 43.90 to $23.20 \mathrm{~m}$ sub-bottom, followed by unusually low ones through $17.74 \mathrm{~m}$ (Fig. 3, Curve B). Moreover, since rare occurrences of $C$. macintyrei are also recorded in topmost Zone NN21 sediments at $0.40 \mathrm{~m}$ sub-bottom depth (Lohman, this volume), and the Olduvai event (1.661.88 m.y.) has now been tentatively identified from $32-$ $36 \mathrm{~m}$ sub-bottom (Barton and Bloemendal, this volume), the stratigraphic significance of the species at Site 593 requires further investigation.

\section{METHODS}

During routine shipboard sampling of Hole 593, $131 \times 10 \mathrm{~cm}^{3}$ samples were collected at 30-40-cm intervals from Cores 593-1 through 593-6, averaging four samples per core section or, for the Quaternary period, one sample per $17,500 \mathrm{yr}$. The very large numbers of samples requested by other scientists from Hole 593 precluded a more detailed sampling program at that time. Additional samples were subsequently obtained to increase the time-stratigraphic resolution in Cores 1 through 3 to about 5000 yr. but results of these will be presented elsewhere.

From 5 to $10 \mathrm{~cm}^{3}$ of each sample was placed overnight in a $50-\mathrm{ml}$ widemouth flask containing $\mathrm{pH} 9.4$ buffer solution prepared by adding $4 \mathrm{~g} \mathrm{NaHCO}_{3}$ and $1 \mathrm{~g} \mathrm{Na}_{2} \mathrm{CO}_{3}$ to $20 \mathrm{l}$ of distilled water (Hay, 1977). Samples were gently agitated on an auto-shaker for 10-15 min. and then washed with buffer solution through a $63-\mu \mathrm{m}$ mesh sieve. The $<63-\mu \mathrm{m}$ mud fraction (silt plus clay) settled overnight and the supernatant liquid was poured off to give a $50-\mathrm{ml}$ volume suspension. This was shaken, $5-\mathrm{ml}$ aliquot extracted by pipette, and the suspended mud concentrated onto preweighed Millipore filters to determine $(\times 10)$ the total weight of mud in the original sample. The remaining mud suspension was split and one portion was washed further over a $25-\mu \mathrm{m}$ mesh sieve and the $<4-\mu \mathrm{m}$-sized material siphoned off following settling of the 4-25- $\mu \mathrm{m}$ fraction. A suspension of the latter was examined using a scanning electron microscope (SEM) to note nannofossil abundance, and the remainder was dried and stored at $4^{\circ} \mathrm{C}$ for isotope analysis.

The sand fraction $(>63 \mu \mathrm{m})$ was washed with distilled water, sonic probed for $10 \mathrm{~s}$, and rinsed again over a $63-\mu \mathrm{m}$-mesh sieve to remove any released fines. The sand was washed on to filter paper, rinsed three times, dried, weighed, and the percentage of sand was deter- 


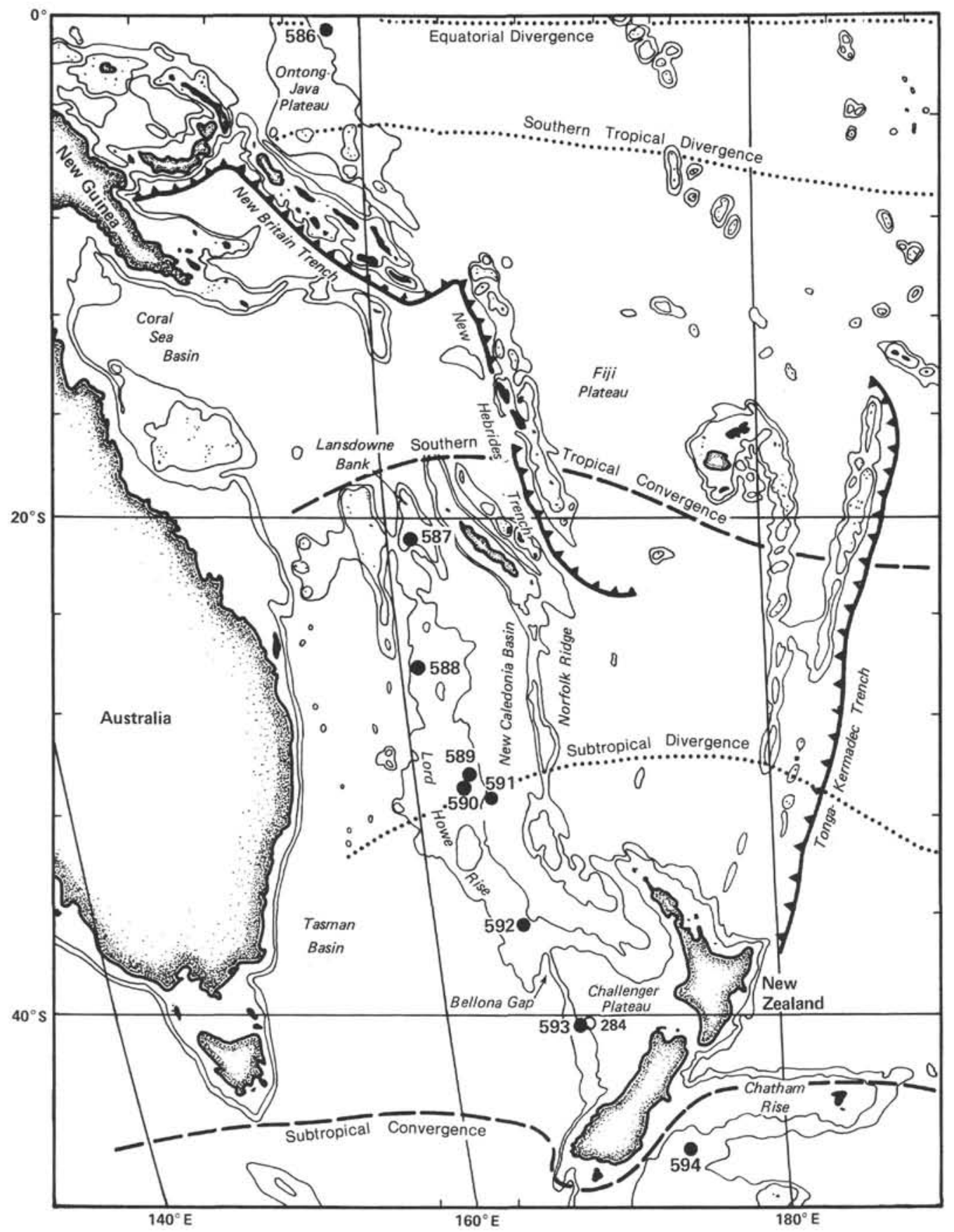

Figure 1. Location of Site 593 and Site 284 (Leg 29) with respect to other Leg 90 sites in the southwest Pacific and approximate position of boundaries between present-day surface water masses (after Knox, 1970). Contour lines show depths of 1 and $2 \mathrm{~km}$.

mined. The dry sand was sieved over a $125-\mu$ m mesh screen, the $>125-$ $\mu \mathrm{m}$ fraction weighed to determine "coarse" sand content, and from it were picked up to 40 specimens of each of the benthic foraminifer Uvigerina sp. or, where rare or absent, Cibicides sp., and a uniform size fraction of the planktonic foraminifer Globigerina bulloides d'Orbigny. Methanol was added to the vials containing the foraminiferal concentrates, samples were sonic probed for 2 min., and the methanol was allowed to evaporate. The cleaned foraminifers were then checked and recounted, discarding any unsuitable specimens.

Purified foraminiferal samples and $\sim 1 \mathrm{mg}$ of the nannofossil samples were vacuum roasted at $400^{\circ} \mathrm{C}$ to remove any residual organic contaminants, crushed, and reacted with $100 \%$ orthophosphoric acid at $50^{\circ} \mathrm{C}$ until visible effervescence ceased, typically after $10-30 \mathrm{~min}$. The evolved carbon dioxide and water were immediately removed by freezing at liquid nitrogen temperatures, and noncondensible gases were pumped away. The carbon dioxide was distilled from any other condensible gases at $-110^{\circ} \mathrm{C}$ and passed directly into the cold finger inlet of a VG Micromass $602 \mathrm{E}$ mass spectrometer. The sample was compared to a working standard consisting of subsamples of a large volume of carbon dioxide prepared as previously described by reaction of Te Kuiti Limestone (TKL; Blattner and Hulston, 1978). This in turn was checked daily against carbon dioxide from the USGS Toilet Seat Marble standard, equivalent to NBS-19 (Coplen et al., 1983), and/or NBS-20 (Craig, 1957). Results are reported in standard notation as per 


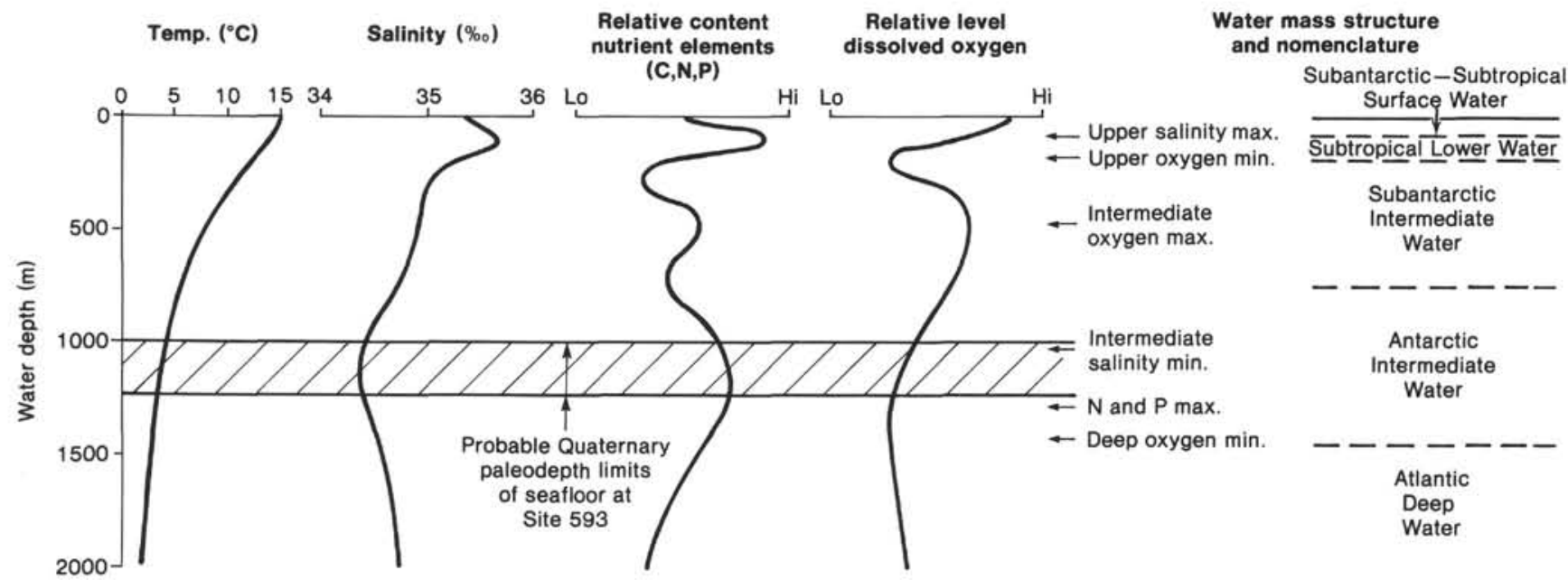

Figure 2. Vertical structure in water mass properties for the southern Tasman Sea in the vicinity of Site 593 (adapted from Rochford, 1960a, 1960b;

Dal Pont and Newell, 1963; Knox, 1970).

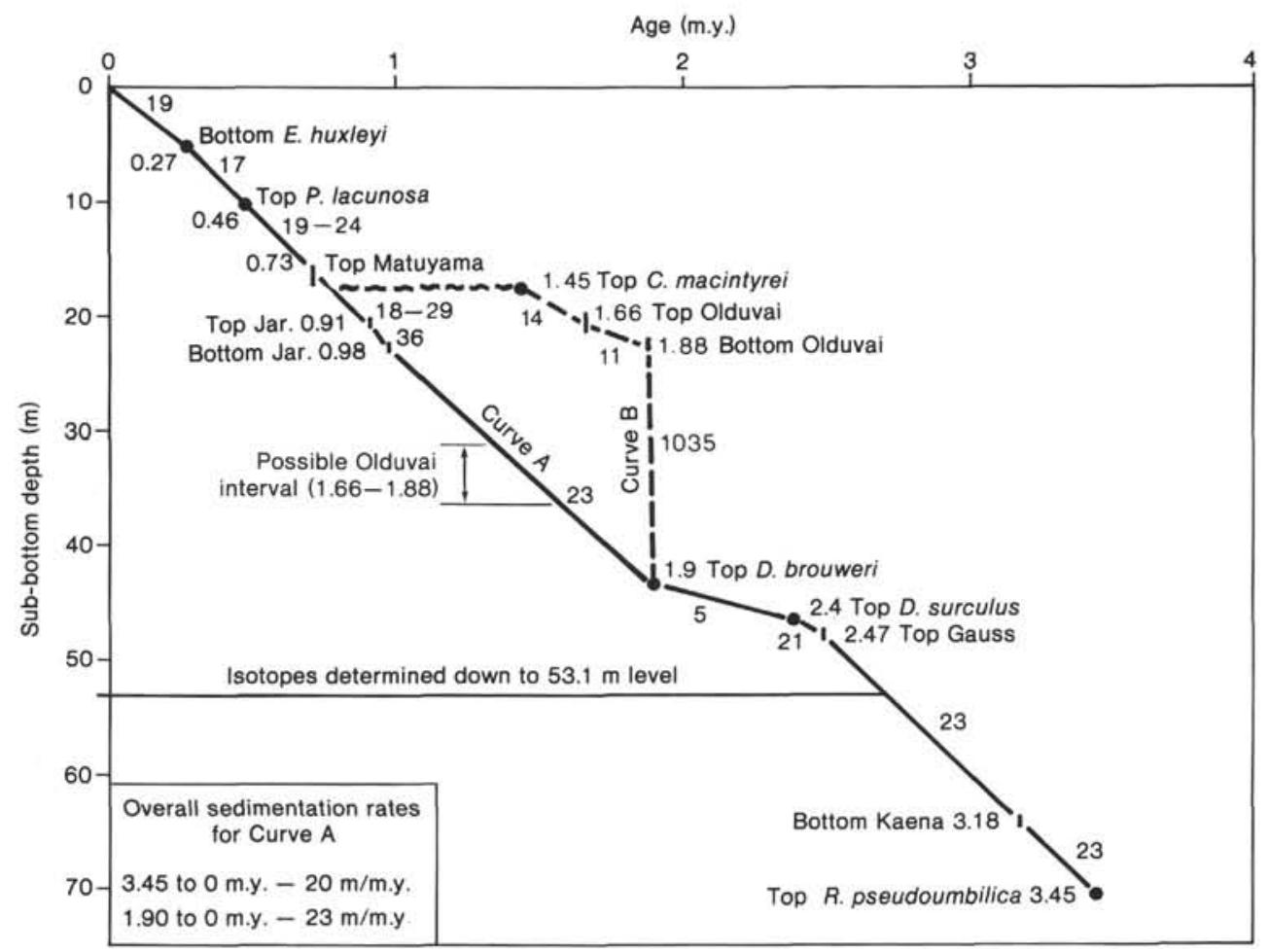

Figure 3. Age versus sub-bottom depth plot for late Pliocene to Recent interval of Hole 593. Whole numbers refer to sedimentation rates (m/m.y.) between the dated (m.y.) calcareous nannofossil and magnetostratigraphic levels. Curve A (solid line) is the preferred relationship; alternative Curve B (dashed line and unconformity) is discounted (see text). After this chapter was completed, Barton and Bloemendal (this volume) tentatively recognized the Olduvai Subchron from about $32-36 \mathrm{~m}$ sub-bottom depth, shown against Curve $\mathrm{A}$.

mil $(\%)$ deviations from the international PDB standard. The standard deviation from the mean value for replicate analyses of $\delta^{18} \mathrm{O}$ of Toilet Seat Marble was $0.04 \% 0(n=42)$, but for NBS-20 the standard deviation was $0.21 \%(n=72)$ which may question the value of NBS20 as an international isotope standard. This problem is currently being investigated. Replicate analyses of 8 microfossil concentrates gave reproducibility in the range $0.10 \pm 0.05 \%$; however, insufficient replicates have been run to enable a meaningful standard deviation to be calculated.

\section{RESULTS AND INTERPRETATION}

Analytical results are listed in Table 1 and graphically displayed in Figure 4.

The benthic foraminifer Uvigerina precipitates its test close to oxygen isotope equilibrium with the surrounding water (Shackleton, 1974) and so is regarded as a reliable indicator of bottom-water composition and/or tem- 
Table 1. Grain-size ratios (s:m, sand-to-mud; cs:fs, coarse sand-tofine sand) and oxygen and carbon isotope values $(\% 0)$ for samples from the latest Pliocene through Quaternary interval of Hole 593.

\begin{tabular}{|c|c|c|c|c|c|}
\hline $\begin{array}{c}\text { Sample } \\
\text { (core-section. }\end{array}$ & $\begin{array}{c}\text { Sub- } \\
\text { bottom } \\
\text { depth }\end{array}$ & $\begin{array}{r}\text { Grai } \\
\mathrm{ra}\end{array}$ & $\begin{array}{l}\text {-size } \\
\text { os }\end{array}$ & $\begin{array}{l}\text { Plan } \\
\text { foran }\end{array}$ & $\begin{array}{l}\text { nic } \\
\text { fers }\end{array}$ \\
\hline & & $\mathrm{s}: \mathrm{m}$ & cs:fs & ${ }_{8}^{18} \mathrm{O}$ & ${ }_{b^{13} \mathrm{C}}$ \\
\hline $1-1,30$ & 0.31 & 0.29 & 1.81 & 3.75 & 1.27 \\
\hline $1-1,56$ & 0.57 & 0.97 & 3.08 & 3.70 & 1.13 \\
\hline $1-1,80$ & 0.81 & 0.68 & 1.85 & 2.97 & 1.56 \\
\hline $1-1,128$ & 1.29 & 0.36 & 1.89 & 3.06 & 1.70 \\
\hline $1-2,30$ & 1.81 & 0.43 & 1.66 & 2.90 & 1.54 \\
\hline $1-2,56$ & 2.07 & 0.81 & 2.07 & 2.22 & 1.07 \\
\hline $1-2,80$ & 2.31 & 0.28 & 1.83 & 3.24 & 1.09 \\
\hline $1-2,128$ & 2.79 & 0.26 & 1.30 & 2.88 & 1.22 \\
\hline $1-3,30$ & 3.31 & 0.18 & 1.36 & 3.17 & 1.25 \\
\hline $1-3,56$ & 3.57 & 0.49 & 1.80 & 3.03 & 1.10 \\
\hline $1-3,80$ & 3.81 & 0.69 & 2.26 & 76 & 1.17 \\
\hline $1-3,128$ & 4.29 & 0.67 & 1.60 & 62 & 1.26 \\
\hline $1-4,30$ & 4.81 & 0.34 & 1.93 & 2.39 & 0.60 \\
\hline $1-4,56$ & 5.07 & 0.58 & 1.60 & 58 & 1.00 \\
\hline $2-1,30$ & 5.41 & 0.09 & 0.05 & 1.31 & 1.45 \\
\hline $2-1,80$ & 5.91 & 0.36 & 2.08 & 3.51 & 1.43 \\
\hline $2-1,128$ & 6.39 & 0.16 & 1.45 & 2.93 & 1.13 \\
\hline $2-1,143$ & 6.54 & 1.36 & 1.39 & 2.51 & 1.26 \\
\hline $2-2,30$ & 6.91 & 0.42 & 4.65 & 2.14 & 1.15 \\
\hline $2-2,80$ & 7.41 & 0.18 & 1.25 & 2.24 & 0.81 \\
\hline $2-2,128$ & 7.89 & 0.19 & 1.39 & 1.55 & 0.90 \\
\hline $2-2,143$ & 8.04 & 0.43 & 1.35 & 2.74 & 0.70 \\
\hline $2 \cdot 3,30$ & 8.41 & 0.18 & 1.93 & 3.46 & 1.08 \\
\hline $2-3,80$ & 8.91 & 0.19 & 2.28 & 3.27 & 1.02 \\
\hline $2-3,12$ & 9.39 & 0.15 & 1.41 & 2.59 & 0.20 \\
\hline $2-3,14$ & 9.54 & 0.36 & 1.21 & 2.25 & 0.50 \\
\hline $2-4,3$ & 9.91 & 0.22 & 1.57 & 2.55 & 1.31 \\
\hline $2-4,8$ & 10.41 & 0.15 & 1.28 & 03 & 40 \\
\hline $2-4,1$ & & 0.13 & 1.28 & 36 & .76 \\
\hline $2-4,1$ & & 0.43 & 1.23 & 54 & 1.01 \\
\hline $2-5,3$ & & 0.14 & 1.49 & 17 & 1.39 \\
\hline $2-5,8$ & & 0.21 & 1.04 & & 0.34 \\
\hline $2-5,1$ & & 0.19 & 1.16 & i. & - \\
\hline $2-5,1$ & & 0.68 & 1.43 & & 1.71 \\
\hline $2-6,3$ & & 0.25 & 1.41 & & 31 \\
\hline $2-6,8$ & & 0.76 & 1.54 & & 41 \\
\hline $2-6,1$ & & 0.52 & 1.73 & & 54 \\
\hline $3-1,30$ & & 0.81 & 2.33 & & 0.37 \\
\hline $3-1,56$ & & 1.24 & 1.38 & & -0.16 \\
\hline $3-1,80$ & & 0.64 & 1.77 & & 0.57 \\
\hline $3-1,128$ & & 0.24 & 1.94 & & 3 \\
\hline $3-2,30$ & & 1.20 & 1.32 & & \\
\hline $3-2,56$ & 16.76 & 0.42 & 1.3 & & \\
\hline $3-2,80$ & & 0.20 & 1.32 & & 0.50 \\
\hline $3-2,128$ & 17.48 & 0.53 & 1.33 & 33 & 0.88 \\
\hline $3 \cdot 3,30$ & & 0.62 & 1.91 & 99 & 1.14 \\
\hline $3-3,56$ & 18.26 & 0.81 & 1.54 & 32 & 1.08 \\
\hline $3-3,80$ & 18.50 & 0.48 & 1.57 & 88 & 1.13 \\
\hline $3-3,128$ & 18.98 & 0.46 & 1.93 & 42 & 1.08 \\
\hline $3-4,30$ & 19.50 & 0.25 & 1.34 & 12 & 1.30 \\
\hline $3-4,56$ & 19.76 & 0.47 & 1.51 & 7 & 1.69 \\
\hline $3-4,80$ & 20.00 & 0.30 & 1.73 & 12 & 1.94 \\
\hline $3-4,128$ & 48 & 0. & 4.34 & 24 & 1.06 \\
\hline $3-5,30$ & 00 & 0.31 & 1.33 & 9 & 1.51 \\
\hline $3-5,56$ & & 0.33 & 0.67 & 26 & 0.97 \\
\hline $3.5,8$ & & 1.74 & 0.05 & 6 & 0.12 \\
\hline $3-5,12$ & & 0.21 & 1.53 & 2 & 1.68 \\
\hline $3-6,3$ & & 0.29 & 1.45 & & 06 \\
\hline 3. & & 1.05 & 1.82 & 9 & 15 \\
\hline 3. & & & 2.61 & & 04 \\
\hline $3.6,1$ & & & 1.52 & & 45 \\
\hline 4 & & & 1.82 & & 1.47 \\
\hline 4 & & & 0.88 & & \\
\hline 4 & & & 1.28 & & \\
\hline 4 & & & 1.57 & & \\
\hline 3 & & & & & \\
\hline 4. & & & & & \\
\hline $4-2,8$ & & & & & \\
\hline $4-2,1$ & & & & & \\
\hline 4. & & & & & \\
\hline 4. & & & & & \\
\hline 4. & & & 1.20 & & \\
\hline 4 & & & & & \\
\hline & & & & & \\
\hline & & & & & \\
\hline & & & 0. & & \\
\hline $4-4,12$ & & & i. & & \\
\hline$=5$ & & & & & \\
\hline & & & 1. & & \\
\hline & & & & & \\
\hline 12 & & & 1. & & \\
\hline & & & & & \\
\hline & & & & & \\
\hline & & & & & \\
\hline & & & & & \\
\hline & & & & & \\
\hline & & & & & \\
\hline & & & & & \\
\hline & & & & & \\
\hline & & & i. & & \\
\hline 8 & 36.21 & 0.26 & 1.27 & 1.92 & $\begin{array}{l}1.55 \\
1.50\end{array}$ \\
\hline
\end{tabular}

Table 1. (Continued).

\begin{tabular}{|c|c|c|c|c|c|c|c|c|c|}
\hline \multirow{2}{*}{$\begin{array}{c}\text { Sample } \\
\text { (core-section, } \\
\text { interval in } \mathrm{cm} \text { ) }\end{array}$} & \multirow{2}{*}{$\begin{array}{l}\text { Sub- } \\
\text { bottom } \\
\text { depth } \\
\text { (m) }\end{array}$} & \multicolumn{2}{|c|}{$\begin{array}{c}\text { Grain-size } \\
\text { ratios } \\
\end{array}$} & \multicolumn{2}{|c|}{$\begin{array}{l}\text { Planktonic } \\
\text { foraminifers }\end{array}$} & \multicolumn{2}{|c|}{$\begin{array}{c}\text { Benthic } \\
\text { foraminifers }\end{array}$} & \multicolumn{2}{|c|}{$\begin{array}{c}\text { Bulk } \\
\text { nannofossils }\end{array}$} \\
\hline & & $\mathrm{s:m}$ & cs:fs & ${ }_{\delta^{18}} \mathrm{O}$ & ${ }_{\delta^{13} \mathrm{C}}$ & ${ }_{8}^{18} \mathrm{O}$ & ${ }_{8^{13} \mathrm{C}}$ & $8^{18} \mathrm{O}$ & ${ }^{13} \mathrm{C}$ \\
\hline$-2,128$ & 36.69 & 0.3 & 1.3 & 1. & 1.73 & 2.67 & 0.91 & 2.03 & 2.28 \\
\hline & & & 0. & & 1.35 & $2.47^{\circ}$ & $1.16^{*}$ & 1.71 & 1.58 \\
\hline$-3,5$ & 37.4 & 0.9 & 1.4 & 2.0 & 1.54 & $2.22^{\circ}$ & $78^{\circ}$ & 2.04 & 1.65 \\
\hline-3 & 3 & 0. & 2.7 & 1.47 & 1.30 & $2.08^{\circ}$ & & 1.53 & 1.17 \\
\hline $5-3,1$ & & 0.3 & 1.2 & & 1.43 & $2.41^{\circ}$ & $1^{*}$ & 2.23 & 2.18 \\
\hline $5-4,3$ & & & i. & & 1.72 & & & 1.53 & 1.75 \\
\hline 4. & & & i. & & & & $0^{\circ}$ & 1.93 & 1.71 \\
\hline 4. & & & i. & & 1.35 & 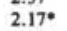 & $3^{\circ}$ & 1.94 & 1.89 \\
\hline 4, & & & i. & & & & & 2.04 & 1.79 \\
\hline $5-5,3$ & & & $i$. & & 2 & & $15^{\circ}$ & 1.77 & 1.93 \\
\hline 5-5, & & & & & & & & 157 & 1.70 \\
\hline & & & & & & & & & 19 \\
\hline & & & & & & & $6^{*}$ & & 48 \\
\hline & & & & & & & 13** & & 92 \\
\hline & & & & & & & $2^{*}$ & & 64 \\
\hline & & & & & & & & & 61 \\
\hline & & & & & & & & & \\
\hline & & & & & & & & & 82 \\
\hline & & & & & & & & & \\
\hline 6. & & & & & & & & & \\
\hline & & & & & & & & & \\
\hline & & & & & & & & & \\
\hline & & & & & & & & & \\
\hline & & & & & & & & & \\
\hline & & & & & & & & & \\
\hline & & & & & & & & & \\
\hline & & & & & & & & & \\
\hline & & & & & & & & & 2.15 \\
\hline & & & 1.98 & & & & & & \\
\hline & & & . & & & 2.01 & 0.9 & & 1.01 \\
\hline & & & 1.21 & & & - & - & & 1.67 \\
\hline & & & & & & - & - & & \\
\hline & & & & & & E. & - & & 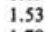 \\
\hline & & & & & & & & & 79 \\
\hline & & & & & & & & & \\
\hline & & & & & & & & & \\
\hline & & & & & & & & & \\
\hline & & & & & & & & & \\
\hline & & & 1. & & & & & & 1.76 \\
\hline $6-6,128$ & 52.29 & 0.22 & 1.48 & 0.69 & 0.93 & 2.58 & 0.46 & 1.64 & 1.77 \\
\hline
\end{tabular}

Note: Measurements for planktonic foraminifers are on Globigerina bulloides, for benthic forafossil concentrates from the $4-25 \mu \mathrm{m}$ sediment-size fraction., - , not determined.

perature (Vincent et al., 1981; Duplessy et al., 1984). Where Cibicides specimens had to be analyzed because of low abundance of Uvigerina in samples, their isotope values have been converted to nominal Uvigerina values for display purposes by the addition of $0.64 \% 0$ to the $\mathrm{Ci}$ bicides $\delta^{18} \mathrm{O}$ values and by subtracting $0.90 \%$ from the Cibicides $\delta^{13} \mathrm{C}$ results (Shackleton and Opdyke, 1973; Shackleton and Cita, 1979; Duplessy et al., 1984).

Globigerina bulloides is a common species of the modern subantarctic assemblages of planktonic foraminifers (Kennett, 1969; Kennett and Vella, 1975; Vella et al., 1975). It has been widely used previously in isotope studies of cores from the Southern Ocean as an indicator of near-surface water mass characteristics (e.g., Hays et al., 1976a, 1976b; Kennett et al., 1979), although Kennett et al. (1979) suggested that the species may have undergone some vertical migration in the water column relative to other planktonic foraminifers.

The isotope results for the nannofossils are bulk values derived from relatively pure $(>90 \%)$ polyspecific calcareous nannofossil concentrates. Since Dudley et al. $(1980,1982)$ have shown differing biological fractionations for different nannofossil species, the isotope composition of the bulk nannofossil samples cannot be interpreted as a function of ocean composition and temperature until species abundances are known. 


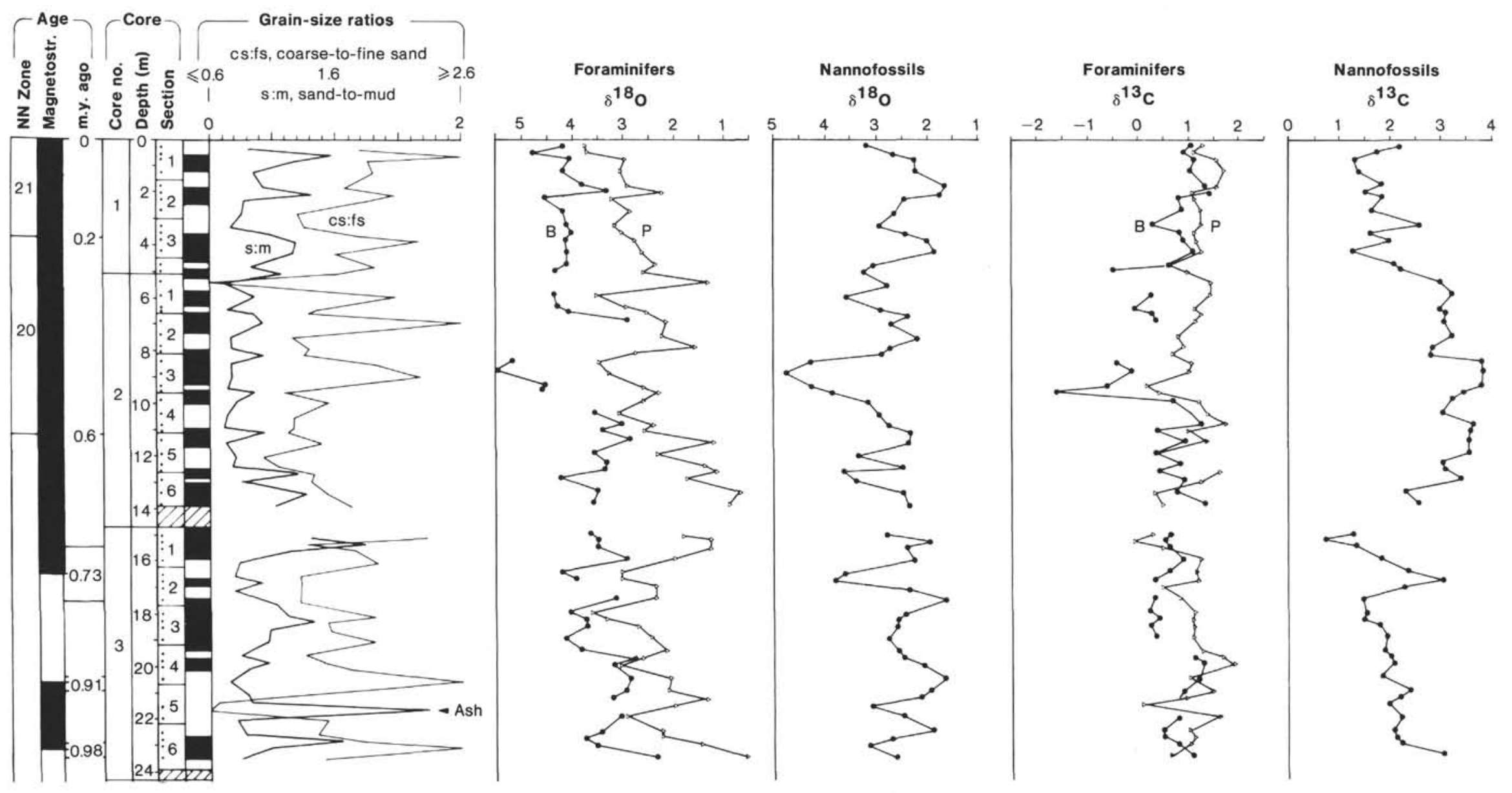



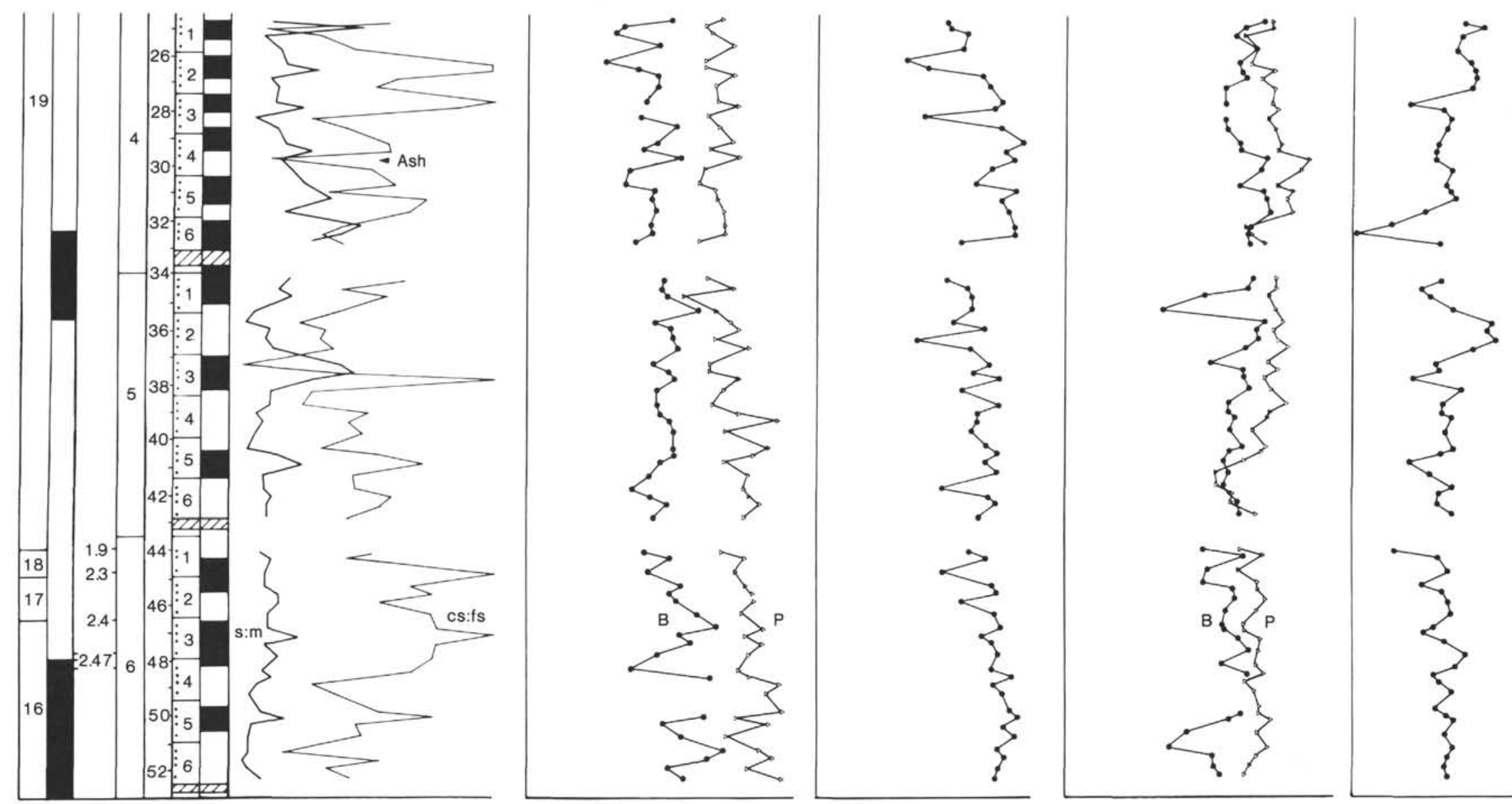

Figure 4. Sediment texture and oxygen and carbon stratigraphic logs for the latest Pliocene through Quaternary interval of Hole 593. Magnetic record shows in black from top to bottom the Brunhes Normal Chron, the Jaramillo Normal Subchron, possible Olduvai Normal Subchron (1.66-1.88 m.y.; Barton and Bloemendal, this volume), and the upper part of the Gauss Norma Chron. Alternating black-and-white intervals down the grain-size log correspond to relatively coarser and finer sediment zones, respectively. Isotope values are in per mil deviations ( $\%$ ) from the international PDB standard. B, benthic foraminiferal curve based on Uvigerina sp. and sometimes Cibicides sp. (see Table 1), the latter having been converted to nominal Uvigerina values for display purposes (see text for explanation); P, planktonic foraminiferal curve based upon Globigerina bulloides. 


\section{Sediment Texture}

Detailed textural analysis of the samples is in progress and only the ratios of sand $(>63 \mu \mathrm{m})$ to mud $(<63 \mu \mathrm{m})$ and of coarse $(>125 \mu \mathrm{m})$ to fine $(63-125 \mu \mathrm{m})$ sand are mentioned briefly here. Variations in both ratios reflect mainly the changing abundances of foraminifers in samples. An increase in the sand-to-mud (s:m) ratio corresponds with an increase in the content of both whole and broken foraminifers in samples, whereas the higher ratios of coarse-to-fine sand (cs:fs) reflect mainly larger numbers of mature, whole foraminifers in samples. In the vicinity of two ash layers (Fig. 4) the sand fraction includes, or is dominated by, glass shards (Nelson, Froggatt, et al., this volume).

Cyclical changes in the s:m and cs:fs ratios occur in the core (Fig. 4). The sand content of samples varies from about 10 to rarely as much as $50 \%$ and is dominated mainly by coarse sand, forming $50-70 \%$ of the sand fraction. With some exceptions the two ratio curves are broadly in phase, although the intensity of ratio fluctuations is more marked for the cs:fs curve. A very tentative scheme of alternating grain-size zones, each characterized by an overall relative increase or decrease in sediment coarseness compared to its neighboring zone, is suggested in Figure 4. The coarser textured intervals are generally more conspicuously burrowed and darker colored (light gray to greenish gray) than the finer oozes (very light gray) and, from the broad relationship between sediment color and isotope stages (Table 2), the coarser oozes apparently are associated mainly with glacial periods.

In other Pacific Ocean cores, glacial stage sediments are generally characterized by less dissolution of foraminifers than are interglacial ones (e.g., Thompson and Saito, 1974; Shackleton and Opdyke, 1976; Volat et al., 1980) and they are therefore relatively coarser grained. The shallowness $(1068 \mathrm{~m})$ of Site 593 , well above the lysocline depth of about $2500 \mathrm{~m}$ at $40^{\circ} \mathrm{S}$ in the Pacific (Berger, 1976), as well as the excellent preservation of both foraminifers and nannofossils in Challenger Plateau cores (see the Site 593 report, this volume; Jenkins, 1975; Kennett and Vella, 1975; Hornibrook, 1982), argue against dissolution as a major factor controlling the

Table 2. Relationship between isotope stages and sediment color in the top $19 \mathrm{~m}$ of core in Hole 593.

\begin{tabular}{|c|c|c|c|c|c|c|c|}
\hline \multirow{2}{*}{$\begin{array}{l}\text { Interglacial } \\
\text { isotope } \\
\text { stage }\end{array}$} & \multicolumn{3}{|c|}{ Sediment color $^{\mathrm{a}}$} & \multirow{2}{*}{$\begin{array}{c}\text { Glacial } \\
\text { isotope } \\
\text { stage }\end{array}$} & \multicolumn{3}{|c|}{ Sediment color } \\
\hline & N8 & N7 & $5 G Y$ & & N8 & N7 & $5 G Y$ \\
\hline 1 & $\mathrm{X}$ & & & 2 & & $x$ & \\
\hline 3 & & & $x$ & 4 & & & $\mathrm{X}$ \\
\hline 5 & $\mathrm{X}$ & $\mathrm{X}$ & & 6 & & $\mathrm{x}$ & $\mathrm{X}$ \\
\hline 7 & $\mathrm{X}$ & $\mathrm{X}$ & & 8 & & & $\mathrm{X}$ \\
\hline 9 & $\mathrm{X}$ & & & 10 & & $\mathrm{x}$ & $\mathrm{X}$ \\
\hline 11 & $\mathrm{X}$ & & $x$ & 12 & $\mathrm{X}$ & & \\
\hline 13 & $\mathrm{x}$ & & & 14 & $\mathrm{x}$ & & \\
\hline 15 & $\mathrm{X}$ & & & 16 & & & $\mathrm{X}$ \\
\hline 17 & & & $\mathrm{X}$ & 18 & & $\mathrm{X}$ & \\
\hline 19 & $\mathrm{X}$ & & & 20 & $\mathrm{x}$ & & $\mathrm{x}$ \\
\hline 21 & $\mathrm{X}$ & & & 22 & $x$ & & \\
\hline 23 & & $X$ & $X$ & & & & \\
\hline
\end{tabular}

${ }^{a} \mathrm{~N} 8=$ very light gray; $\mathrm{N} 7=$ light gray; $5 \mathrm{GY}=$ greenish gray. grain-size variations. Instead, the topographic elevation of the site (Fig. 1) and its coincidence in depth with the north-flowing core of Antarctic Intermediate Water (Fig. 2) suggest that changes in the rates of lateral transport or intensity of winnowing by bottom currents may have been the principal factors determining sediment texture. The general correspondence between darker colored oozes, relatively coarser sediment intervals, and glacial isotope stages at Site 593 is then compatible with the more intensified patterns of ocean circulation commonly ascribed to glacial conditions (Valencia, 1977; Volat et al., 1980).

\section{Oxygen Isotope Stratigraphy}

The foraminiferal oxygen isotope record for the last $1 \mathrm{~m} . \mathrm{y}$. has been compared (Fig. 5) to the records from other long-duration cores, in particular those from the western Caribbean DSDP Hole 502 (Prell, 1982) and the equatorial Pacific Core V28-239 (Shackleton and Opdyke, 1976). It is evident that despite our rather large sampling interval of about 17,500 yr., sufficient detail is present to allow tentative identification of most of the standard isotope stages (Emiliani, 1955; Shackleton and Opdyke, 1976). In particular, the major glacial-interglacial transitions are recognizable with the exception of boundary $17 / 18$, which appears to fall within the gap between Cores 593-2 and 593-3, and of transition 11/12, which is subdued. The coarse sampling interval dictated by DSDP shipboard sampling restrictions has provided only about 3 to 6 points per glacial-interglacial cycle. This has made detailed correlation between this record and those of other cores difficult as the highs, lows, and fine structure of each glacial-interglacial cycle are not necessarily located. Furthermore, it is not possible to distinguish between the loss of parts of isotope stages through winnowing as opposed to absence occasioned by their lying between sample points.

Correlation is aided by the magnetostratigraphy (Fig. 5), which enables placement of the $19 / 20$ boundary at the conclusion of the Matuyama Chron, and of the 23/ 24 boundary at the close of the Jaramillo Subchron, and is further strengthened by the last appearance of Pseudoemiliania lacunosa at $9.91 \mathrm{~m}$ at the isotope stage 11/ 12 boundary, and the first appearance of Emiliania huxleyi at $5.07 \mathrm{~m}$ within isotope stage 7 . These are consistent with the results of Thierstein et al. (1977) who found $P$. lacunosa extinction during isotope stage 12 and the first appearance of $E$. huxleyi during isotope stage 8 . It has proved difficult to resolve positively the isotope stages between the base of the Brunhes and the base of the Jaramillo, because at Site 593 only one glacial stage was identified within the Jaramillo, and three were identified between the top of the Jaramillo and the base of the Brunhes. It is our opinion that isotope stage 23 occurs at about $20 \mathrm{~m}$ sub-bottom, and that the apparent discrepancy between this and the level of the top of the Jaramillo may be resolved by sampling at closer intervals. Below the Jaramillo our oxygen isotope record is of little assistance in establishing a chronology for the core since the magnitude of glacial-interglacial changes in $\delta^{18} \mathrm{O}$ is smaller and their frequency greater, a situation seen also in the other cores (Fig. 5) and elsewhere (e.g., 


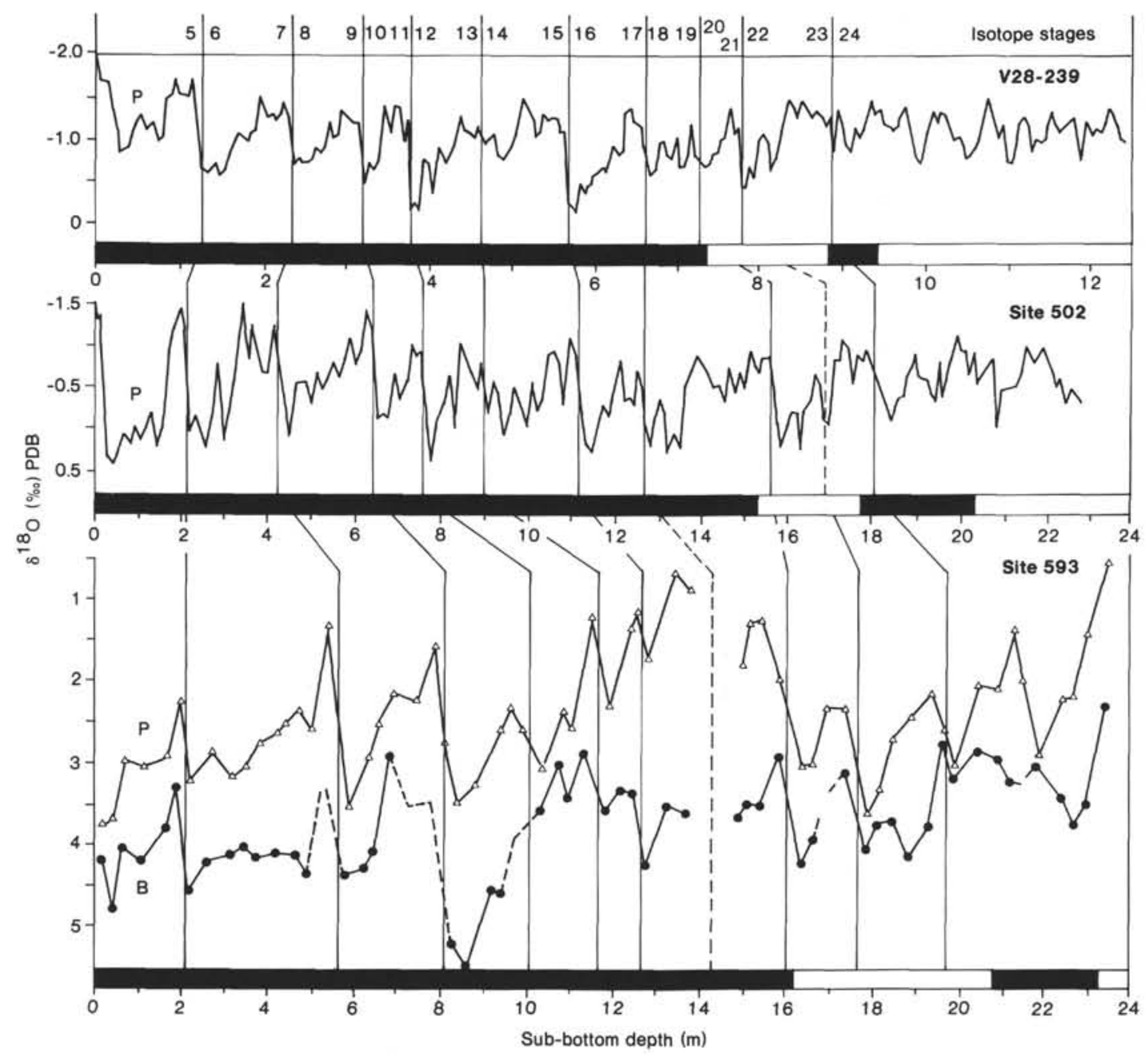

Figure 5. Occurrence of numbered standard isotope stages in late Pleistocene interval of Hole 593 based on correlation with cores at DSDP Site 502 (Prell, 1982) and Core V28-239 (Shackleton and Opdyke, 1976). Note the increasing scale of thickness from Core V28-239 to DSDP Sites 502 and 593. Black bars correspond to Brunhes Normal Chron (0-0.73 m.y.) and Jaramillo Normal Subchron (0.91-0.98 m.y.) intervals. B, benthic foraminiferal curve; P, planktonic foraminiferal curve.

Van Donk, 1976). The importance of this shift in average and amplitude of the $\delta^{18} \mathrm{O}$ signal at about $900 \times 10^{3}$ yr. ago has been emphasized by Pisias and Moore (1981) and Prell (1982). It reflects a fundamental change in the global ice budget between the early and late Quaternary and has been related to major expansion of Arctic ice sheets and development of large floating Arctic Ocean ice masses at about the time of the Jaramillo Subchron (Williams et al., 1981).

Despite the limitations in identification of isotope stage boundaries, we have used those indicated in Figure 5, in conjunction with the established ages of the isotope stage boundaries (Imbrie et al., in press) and the magnetic datum points, to estimate average sedimentation rates in the core (Table 3 ). These vary between 1.66 and $3.13 \mathrm{~cm} / 10^{3} \mathrm{yr}$. and are sufficiently high to minimize the smoothing of the isotope record as a result of sediment mixing by organisms (Shackleton and Opdyke, 1976), especially since bioturbation is apparently not intensive in the cores (Nelson, this volume). Consequently, the coarse sampling intervals have tended to yield a more er-
Table 3. Average sedimentation rates at various times in the Quaternary of Hole 593 based mainly on the position of late Pleistocene isotope stages and their probable ages (Imbrie et al., in press).

\begin{tabular}{|c|c|c|c|}
\hline $\begin{array}{c}\text { Stratigraphic } \\
\text { interval }\end{array}$ & $\begin{array}{c}\text { Sub- } \\
\text { bottom } \\
\text { depth } \\
\text { (cm) }\end{array}$ & $\begin{array}{c}\text { Age } \\
\text { range } \\
\left(\times 10^{3} \mathrm{yr} .\right)\end{array}$ & $\begin{array}{c}\text { Sedimentation } \\
\text { rate } \\
\left(\mathrm{cm} / 10^{3} \mathrm{yr}\right)\end{array}$ \\
\hline Present-5/6 & $0-215$ & $0-128$ & 1.68 \\
\hline $5 / 6-7 / 8$ & $215-565$ & $128-245$ & 2.99 \\
\hline $7 / 8-9 / 10$ & $565-795$ & $245-338$ & 2.47 \\
\hline $9 / 10-11 / 12$ & $795-1010^{*}$ & $338-427$ & 2.42 \\
\hline $11 / 12-13 / 14$ & $1010^{*}-1185$ & $427-508$ & 2.16 \\
\hline $13 / 14-15 / 16$ & $1185-1380$ & $508-620$ & 1.74 \\
\hline $15 / 16-19 / 20$ & $1380-1620$ & $620-737$ & 2.05 \\
\hline $19 / 20-21 / 22$ & $1620-1770$ & $737-785$ & 3.13 \\
\hline 21/22-Base Jar & $1770-2325$ & $785-980$ & 2.85 \\
\hline Base Jar-M/G & $2325-4800$ & $980-2470$ & 1.66 \\
\hline
\end{tabular}

Note: Jar, M, and G refer to Jaramillo, Matuyama, and Gauss magnetic periods; $5 / 6=$ boundary between stages 5 and 6 , etc. * position inferred. 
ratic curve with a larger spread of $\delta^{18} \mathrm{O}$ values than either Core V28-239 or DSDP Hole 502 (Fig. 5). Furthermore, it appears that no unconformities of more than a few tens of centimeters are possible above the base of the Jaramillo Subchron.

The fluctuations in the $\delta^{18} \mathrm{O}$ record of the planktonic and benthic foraminifers and of the calcareous nannofossils are mainly concordant and match those found in the many deep-sea cores that have been analyzed over the last $30 \mathrm{yr}$. The isotope fluctuations are a response to the combined effects of changing ${ }^{18} \mathrm{O} /{ }^{16} \mathrm{O}$ ratio of ocean water due to the growth and waning of the major ice sheets, and of changing temperature due to climate and ocean circulation changes. The dominant effect during the late Pleistocene has been the growth and recession of ice sheets (Shackleton, 1967), which has resulted in fluctuations in the $\delta^{18} \mathrm{O}$ of benthic and planktonic foraminifers of about $1.6 \%$ on a time scale of approximately 100 $\times 10^{3}$ yr. per cycle.

Several features of the $\delta^{18} \mathrm{O}$ record of Hole 593 deserve comment. Throughout the Pleistocene there is a gradual increase in the average $\delta^{18} \mathrm{O}$ value in all three of the isotope records. Comparing the mean values from below the Jaramillo $(23.4-52.3 \mathrm{~m})$ to those within the Brunhes (0-16.3 m), the planktonic foraminifers increase from 1.56 to $2.41 \%$, the benthic foraminifers increase from 2.93 to $3.95 \%$, and the calcareous nannofossils increase from 1.86 to $2.82 \%$. This long-term increase in $\delta^{18} \mathrm{O}$ is also evident in many other long cores (e.g., Van Donk, 1976; Prell, 1982; Shackleton et al., 1984) and presumably reflects mainly an overall gradual increase in polar ice volume through the Quaternary. For our planktonic foraminiferal record the increase is brought about by a progressively greater difference between the interglacial and glacial values, with the interglacial values remaining within the range of +1.0 to $+1.5 \%$ throughout, whereas the glacial values increase from a range of +2.0 to $+2.5 \%$ in the early Pleistocene to a range of +3.0 to $+3.5 \%$ in the late Pleistocene. Again, a generally similar situation is evident in records from the Indian (Imbrie et al., in press), eastern Pacific (Shackleton and Hall, 1982), and Atlantic (Prell, 1982) oceans.

Compared to the Globigerina bulloides values, the Uvigerina $\delta^{18} \mathrm{O}$ values generally remain approximately $1.5 \%$ more positive during the late Pleistocene interglacial periods and $1.3 \% 0$ more positive during glacial periods. The difference is less than might be predicted from the modern observed temperature gradient of about $10^{\circ} \mathrm{C}$ between surface and bottom waters at Site 593 (Fig. 2). Both records fall within the range of isotope values reported by Kennett et al. (1979) on the basis of their few Quaternary analyses at nearby Site 284. Since Uvigerina has been shown to deposit its test in isotopic equilibrium with seawater (Shackleton, 1974) and is restricted to living at the seafloor, the discrepancy between the planktonic and benthic curves may result from $G$. bulloides depositing at least some of its carbonate at a depth within the water column or within a restricted temperature season. If, however, G. bulloides maintained much the same depth habitat and seasonal growth pat- terns throughout, the change in the difference between the planktonic and benthic curves suggests a glacial-interglacial change in temperature gradient between surface waters and bottom waters of only about $1^{\circ} \mathrm{C}$ in the vicinity of Site 593 throughout the late Pleistocene. This value is less than the $2-4^{\circ}$ cooling of sea-surface temperatures estimated by CLIMAP Project Members (1981) to have occurred in the south Tasman Sea about $18 \times$ $10^{3}$ yr. ago compared to the present day, but may be achieved by a modest cooling of bottom waters (currently $4-5^{\circ} \mathrm{C}$ ) by $1-3^{\circ} \mathrm{C}$.

Whereas the benthic foraminiferal $\delta^{18} \mathrm{O}$ record is generally 1.3 to $1.5 \%$ more positive than the planktonic record, there are several intervals in the core where the two records converge. This is particularly apparent at $35 \mathrm{~m}$, at $22 \mathrm{~m}$ (isotope stage ?26), at $20 \mathrm{~m}$ (isotope stage 24), at $18 \mathrm{~m}$ (isotope stage 22), and at $10.4 \mathrm{~m}$ (isotope stage 12). In each of these instances the isotope convergence has occurred during a glacial period and in three cases it has resulted in a simultaneous decrease in the benthic and increase in the planktonic $\delta^{18} \mathrm{O}$ record. We interpret this as evidence for the development of periods of intensified upwelling over the shallow Challenger Plateau and thus for possible significant changes in the pattern or intensity of circulation of the intermediate waters in the southwest Pacific (Fig. 2) during several of the Pleistocene glaciations. More vigorous current activity at these times can explain the frequent association of coarser oozes with glacial periods as a result of fine sediment winnowing, as mentioned earlier.

An extremely positive excursion of $\delta^{18} \mathrm{O}$ values is recorded in the benthic curve during isotope stage 10 (Fig. 5 ), with $\delta^{18} \mathrm{O}$ values approximately $1 \%$ greater than for other glacial periods. This positive $\delta^{18} \mathrm{O}$ anomaly is matched also by the bulk calcareous nannofossil $\delta^{18} \mathrm{O}$ data (Fig. 4), by the sudden absence of Uvigerina specimens from the benthic foraminiferal population (Table 1), and partly by the occurrence of rather low foraminiferal $\delta^{13} \mathrm{C}$ values over this interval (Fig. 4). We interpret the anomaly as representing the appearance of a major pulse of much colder (by as much as $4^{\circ} \mathrm{C}$ ) bottom waters on the Challenger Plateau at this time (about $350 \times 10^{3} \mathrm{yr}$. ago), although we do not understand the greatly increased nannofossil $\delta^{18} \mathrm{O}$ at this time.

The significant positive $\delta^{18} \mathrm{O}$ excursion of about $1.5 \%$ at $48.5 \mathrm{~m}$ depth occurs close to the Matuyama/Gauss boundary (2.47 m.y.) and is probably an expression of the rapid expansion of Northern Hemisphere ice sheets from about 2.6 to 2.4 m.y. ago (Shackleton and Kennett, 1975a), which involved also the first extensive calving of icebergs into the North Atlantic (Shackleton et al., 1984). Since no corresponding excursion appears in either the planktonic or nannofossil record, we assume that the benthic excursion was the result of a decrease in bottom-water temperatures, with perhaps the appearance of Atlantic Deep Water at Site 593.

The $\delta^{18} \mathrm{O}$ record of the calcareous nannofossils roughly parallels the foraminiferal isotope curves, showing the same long-term increase in $\delta^{18} \mathrm{O}$ through the Pleistocene, and the increasing amplitude of glacial-interglacial cycles over the last $1 \mathrm{~m}$.y. Phase correspondence of 
the $\delta^{18} \mathrm{O}$ signal with the planktonic foraminiferal record is good in Cores 593-1, -2 , and -4 , and fair in Cores 593$3,-5$, and -6 . The overall amplitude of the nannofossil cycles is about $50 \%$ greater than that of the planktonic foraminifers. This probably reflects the consistently shallower $(<150 \mathrm{~m})$ depth habitat of the coccolithophores, which should therefore record the largest glacial-interglacial paleotemperature change, as well as perhaps a damping of the paleotemperature signal provided by the planktonic foraminifers because of migration to different depths during interglacial and glacial periods (Emiliani, 1966). More precise interpretations of the nannofossil curve will have to take into account the effect of species-specific "vital effects" (Dudley et al., 1982) on the overall isotope composition of the nannofossil assemblages sampled.

\section{Carbon Isotope Stratigraphy}

Although the determination of $\delta^{18} \mathrm{O}$ on carbonates usually requires the simultaneous determination of $\delta^{13} \mathrm{C}$, very much less is known about the significance of carbon isotope stratigraphy of oceanic cores, and much of the data produced as a consequence of the oxygen isotope studies remains unpublished. No attempt is made here to interpret the $\delta^{13} \mathrm{C}$ stratigraphy, but the analyses are presented in Table 1 and Figure 4 for completeness.

\section{SUMMARY}

1. The Quaternary section of Hole 593 comprises $43.9 \mathrm{~m}$ of foraminifer-bearing nannofossil oozes, deposited in about $1000 \mathrm{~m}$ water depth at an average rate of $2.3 \mathrm{~cm} / 10^{3} \mathrm{yr}$., from which has been obtained a moderate-resolution (sample/17,500 yr.) isotope stratigraphy for the entire Quaternary (and latest Pliocene) based on analyses of the benthic foraminifer Uvigerina (or Cibicides), the planktonic foraminifer Globigerina bulloides, and bulk calcareous nannofossil samples $(4-25 \mu \mathrm{m})$.

2. All the records show a gradual increase in the average $\delta^{18} \mathrm{O}$ value through the Pleistocene in response to a progressive increase in the volume of ice locked in polar ice sheets. However, despite this long-term increase, maximum interglacial $\delta^{18} \mathrm{O}$ values remain similarly low throughout the record. Two modes of Quaternary $\delta^{18} \mathrm{O}$ variation (Prell, 1982) are evident: low values with generally low variability in the early Quaternary (1.9-1.0 m.y.), and higher values with high variability during the late Quaternary $(<1.0 \mathrm{~m}$.y.). The greatly increased intensity of glacial-interglacial fluctuations since about the start of the Jaramillo Subchron has been related to significant growth of sea ice in the Arctic Ocean (Williams et al., 1981).

3. The standard late Quaternary isotope stages 1-24 are generally resolvable, but uncertainties remain since the coarse sampling intervals have resulted in much of the fine structure being missed.

4. With some exceptions, the benthic and planktonic foraminiferal $\delta^{18} \mathrm{O}$ trends roughly parallel each other, indicating generally little change in the temperature difference between surface and bottom (intermediate) water masses at the site. However, during at least five periods, the $\delta^{18} \mathrm{O}$ values for the benthic and planktonic foraminifers converge closely. These all occur during planktonic $\delta^{18} \mathrm{O}$ maxima, a fact suggestive of intensified upwelling of Antarctic Intermediate Waters over the Challenger Plateau during some glacials. Highly positive $\delta^{18} \mathrm{O}$ values of benthic foraminifers during isotope stage 10 indicate a major, but temporary, intrusion of bottom waters near $0^{\circ} \mathrm{C}$ on to the Plateau around $350 \times 10^{3}$ yr. ago.

5. The calcareous nannofossil $\delta^{18} \mathrm{O}$ record is in good to fair agreement with the foraminiferal curves. The isotope cycles are of greater amplitude, possibly because of an increased temperature effect on the record.

6. Compared to the interglacial oozes (very light gray), the oozes of glacial stages are often darker colored (light gray to greenish gray), more conspicuously burrowed, and coarser grained (foraminifer-enriched). The coarse sediment intervals are ascribed to periods of increased intensity of winnowing by Antarctic Intermediate Bottom Waters.

\section{ACKNOWLEDGMENTS}

We gratefully thank Mark Lawrence, Scott Nodder, Alison Cuthbertson, and Steve Bergin for considerable assistance with sample preparation and operation of the mass spectrometer; Dr. Graham Gibson (Geology Department, University of Auckland) for verification of foraminiferal identifications; Tony Edwards (N.Z. Geological Survey, Lower Hutt) and Dr. Bill Lohman (Marathon Oil Co., Denver) for information relevant to refining microfossil age datums in the core; and Professor Warren Prell (Department of Geological Sciences, Brown University) and an anonymous reviewer for comments of this manuscript. The work was partly financed by University Grants Committee research number $88 / 125$ to C. S. Nelson and by the U.S.-New Zealand Cooperative Science Program (No. 80-N2-05), Division of International Programs, U.S. National Science Foundation.

\section{REFERENCES}

Berger, A. H., 1976. Biogenous deep-sea sediments: production, preservation, interpretation. In Riley, J. P., and Chester, R. (Eds.), Chemical Oceanography (2nd Ed.) London (Academic Press), 5: 265-387.

Blattner, P., and Hulston, J. R., 1978. Proportional variations of geochemical $\delta^{18} \mathrm{O}$ scales-an interlaboratory comparison. Geochim. Cosmochim. Acta, 42:59-62.

Bradford, J. M., and Roberts, P. E., 1978. Distribution of reactive phosphorus and plankton in relation to upwelling and surface circulation around New Zealand. N.Z. J. Mar. Freshw. Res., 12:1-15.

CLIMAP Project Members, 1981. Seasonal reconstructions of the earth's surface at the last glacial maximum. Geol. Soc. Am. Map Chart Ser, MC-36.

Coplen, T. B., Kendall, C., and Hopple, J., 1983. Comparison of stable isotope reference samples. Nature, 302:236-238.

Craig, H., 1957. Isotopic standards for carbon and oxygen and correction factors for mass-spectrometric analysis of carbon dioxide. Geochim. Cosmochim. Acta, 12:133-140.

Dal Pont, G., and Newell, B., 1963. Suspended organic matter in the Tasman Sea. Aust. J. Mar. Freshw. Res., 14:155-165.

Dudley, W. C., Brand, L. E., Blackwelder, P. L., Duplessy, J.-C., and Guillard, R. R. L., 1982. Re-evaluation of calcareous nannofossil oxygen isotope data. Geol. Soc. Am. Abstr. Progr. (Abstract)

Dudley, W. C., Duplessy, J.-C., Blackwelder, P. L., Brand L. E., and Guillard, R. R. L., 1980. Coccoliths in Pleistocene-Holocene nannofossil assemblages. Nature, 285:222-223.

Duplessy, J.-C., Shackleton, N. J., Mathews, R. K., Prell, W., Ruddiman, W. F., Caralp, M., and Hendy, C. H., 1984. ${ }^{13} \mathrm{C}$ Record of benthic foraminifera in the last interglacial ocean: implications for the carbon cycle and the global deep water circulation. Quat. Res, 21:225-243.

Emiliani, C., 1955. Pleistocene temperatures. J. Geol., 63:538-578. 1966. Paleotemperature analysis of Caribbean Cores P6304 8 and P6304-9 and a generalized temperature curve for the past 425,000 years. J. Geol., 74:109-124.

1971. The amplitude of Pleistocene climatic cycles at low latitudes and the isotopic composition of glacial ice. In Turekian, 
K. K. (Ed.), Late Cenozoic Glacial Ages: Hartford (Yale University Press), pp. 183-197.

Emiliani, C., and Flint, R. F., 1963. The Pleistocene record. In Hill, M. N. (Ed.), The Sea (Vol. 3): New York (Wiley), pp. 888-919.

Hay, W. W., 1977. Calcareous nannofossils. In Ramsay, A. T. S. (Ed.), Oceanic Micropalentology, (Vol. 2): London (Academic Press), 1055-1200.

Hays, J. D., Imbrie, J., Shackleton, N. J., 1976a. Variations in the earth's orbit: pacemaker of the ice ages. Science, 194:1121-1132.

Hays, J. D., Lozano, J., Shackleton, N. J., and Irving, G., 1976b. Reconstruction of the Atlantic Ocean and western Indian Ocean sectors of the 18000 B.P. Antarctic Ocean. In Cline, R. M., and Hays, J. D. (Eds.), Investigation of Late Quaternary Paleoceanography and Paleoclimatology. Geol. Soc. Am. Mem., 145:337-372.

Hornibrook, N. de B., 1982. Late Miocene to Pleistocene Globorotalia (Foraminiferida) from DSDP Leg 29, Site 284, Southwest Pacific. N.Z. J. Geol. Geophys., 25:83-99.

Imbrie, J., Shackleton, N. J., Pisias, N. G., Morley, J. J., Prell, W. L., et al., in press. The orbital theory of Pleistocene climate: support from a revised chronology of the marine $\delta^{18} \mathrm{O}$ record. In Imbrie, J., and Berger, A. (Eds.), Milankovitch and Climate Change: Amsterdam (Elsevier).

Jenkins, D. G., 1975. Cenozoic planktonic foraminiferal biostratigraphy of the South Western Pacific and Tasman Sea-DSDP Leg 29. In Kennett, J. P., Houtz, R. E., et al., Init. Repts. DSDP, 29: Washington (U.S. Govt. Printing Office), 449-467.

Kennett, J. P., 1969. Distribution of planktonic foraminifera in surface sediments to the southeast of New Zealand. In Brönniman, P., and Renz, H. H. (Eds.), Proc. First Int. Conf. Plankt. Microfossils, Geneva 1967, 2:307-322.

1983. Paleo-oceanography: global ocean evolution. Rev. Geophys. Space Phys., 21:1258-1274. Hall).

Kennett, J. P., Shackleton, N. J., Margolis, S. V., Goodney, D. E., Dudley, W. C., and Kroopnick, P. M., 1979. Late Cenozoic oxygen and carbon isotopic history and volcanic ash stratigraphy: DSDP Site 284, South Pacific. Am. J. Sci., 179:52-69.

Kennett, J. P., and Shackleton, N. J., 1976. Oxygen isotopic evidence for the development of the psychrosphere $38 \mathrm{M} \mathrm{yr}$ ago. Nature, 260:513-515.

Kennett, J. P., Houtz, R. E., et al., 1975. Init. Repts. DSDP, 29: Washington (U.S. Govt. Printing Office).

Kennett, J. P., and Vella, P., 1975. Late Cenozoic planktonic foraminifera and paleoceanography at DSDP Site 284 in the cool subtropical South Pacific. In Kennett, J. P., Houtz, R. E., et al., Init. Repts. DSDP, 29: Washington (U.S. Govt. Printing Office), 769-799.

Knox, G. A., 1970. Biological oceanography of the South Pacific. In Wooster, W. S., (Ed.), Scientific Exploration of the South Pacific: Washington (National Academy of Sciences), pp. 155-182.

Loutit, T. S., and Kennett, J. P., 1979. Application of carbon isotope stratigraphy to late Miocene shallow marine sediments, New Zealand. Science, 204:1196-1199.

Pisias, N. G., and Moore, T. C., Jr., 1981. The evolution of Pleistocene climate: a time series approach. Earth Planet. Sci. Lett., 52: 450-458.

Prell, W. L., 1982. Oxygen and carbon isotope stratigraphy for the Quaternary of Hole 502B: evidence for two modes of isotopic variability. In Prell, W. L., Gardner, J. V., et al., Init. Repts. DSDP, 68: Washington (U.S. Govt. Printing Office), 455-464.

Rochford, D. J., 1960a. The intermediate depth water of the Tasman and Coral Seas. I. The $27.20 \sigma \mathrm{T}$ surface. Aust. J. Mar. Freshw. Res., 11:127-147.

1960b. The intermediate depth waters of the Tasman and Coral Seas II. The $26.80 \sigma_{\mathrm{T}}$ surface. Aust. J. Freshw. Res., 11: 148-165.

Shackleton, N. J., 1967. Oxygen isotope analyses and Pleistocene temperatures reassessed. Nature, 215:15-17.

1974. Attainment of isotopic equilibrium between ocean water and the benthonic foraminifera genus Uvigerina: isotopic changes in the ocean during the last glacial. Coll. Internat. Centre Nat. Rech. Sci., 219:203-210.

Shackleton, N. J., Backman, J., Zimmerman, H., Kent, D. V., Hall, M. A., Roberts, D. G., Schnitker, D., Baldauf, J. G., Desprairies,
A., Homrighausen, R., Huddlestun, P., Keene, J. B., Kaltenback, A. J., Krumsiek, K. A. O., Morton, A. C., Murray, J. W., and Westberg-Smith, J., 1984. Oxygen isotope calibration of the onset of ice-rafting history of glaciation in the North Atlantic region. Nature, 307:620-623.

Shackleton, N. J., and Cita, M. B., 1979. Oxygen and carbon isotope stratigraphy of benthic foraminifers at Site 397: detailed history of climatic change during the late Neogene. In von Rad, U., Ryan, W. B. F., et al., Init. Repts. DSDP, 47, Pt. 1: Washington (U.S. Govt. Printing Office), 433-445.

Shackleton, N. J., and Hall, M. A., 1982. Stable isotope record of Hole 504 sediments: high resolution record of the Pleistocene. In Cann, J. R., Langseth, M. G., Honnorez, J., Von Herzen, R. P., White, S. M., et al., Init. Repts. DSDP, 69: Washington (U.S. Govt. Printing Office), 431-441.

Shackleton, N. J., Imbrie, J., and Hall, M. A., 1983. Oxygen and carbon isotope record of East Pacific core V19-30: implications for the formation of deep water in the late Pleistocene North Atlantic. Earth Planet. Sci. Lett., 65:233-244.

Shackleton, N. J., and Kennett, J. P., 1975a. Late Cenozoic oxygen and carbon isotope changes at DSDP Site 284: implications for glacial history of the Northern Hemisphere and Antarctica. In Kennett, J. P., Houtz, R. E., et al., Init. Repts. DSDP, 29: Washington (U.S. Govt. Printing Office), 801-807.

1975 b. Paleotemperature history of the Cenozoic and the initiation of Antarctic glaciation: oxygen and carbon isotope analyses in DSDP Sites 277, 279, and 281. In Kennett, J. P., Houtz, R. E., et al., Init. Repts. DSDP, 29: Washington (U.S. Govt. Printing Office), 743-755.

Shackleton, N. J., and Opdyke, N. D., 1973. Oxygen isotope and palaeomagnetic stratigraphy of Equatorial Pacific core V28-238: oxygen isotope temperatures and ice volumes on a $10^{5}$ year and $10^{6}$ year scale. Quat. Res., 39-55.

1976. Oxygen isotope and paleomagnetic stratigraphy of Pacific core V28-239, late Pliocene to latest Pleistocene. In Cline, R. M., and Hays, J. D. (Eds.), Investigation of Late Quaternary Paleoceanography and Paleoclimatology: Geol. Soc. Am. Mem., 145:449-464.

Stanton, B. R., 1973. Circulation along the eastern boundary of the Tasman Sea. In Fraser, R. (Ed.), Oceanography of the South Pacific 1972: Wellington (N.Z. Commission for UNESCO), pp. $141-147$.

Suggate, R. P., Stevens, G. R., and Te Punga, M. T. (Eds.), 1978. The Geology of New Zealand (Vol. 2): Wellington (Govt. Printer), pp. 541-626.

Thierstein, H. R., Geitsenauer, K. R., Molfino, B., and Shackleton, N. J., 1977. Global synchroneity of late Quaternary coccolith datum levels: Validation by oxygen isotopes. Geology, 5:400-404.

Thompson, P. R., and Saito, T., 1974. Pacific Pleistocene sediments: planktonic foraminifera dissolution cycles and geochronology. Geology, 2:333-335.

Valencia, M. J., 1977. Pacific Pleistocene paleoclimatic stratigraphies: a comparative analysis of results. Quat. Res., 8:339-354.

Van Donk, J., 1976. $\mathbf{O}^{18}$ record of the Atlantic Ocean for the entire Pleistocene epoch. In Cline, R. M., and Hays, J. D. (Eds.), Investigation of Late Quaternary Paleoceanography and Paleoclimatology. Geol. Soc. Am. Mem., 145:147-163.

Vella, P., Ellwood, B. B., and Watkins, N. D., 1975. Surface-water temperature changes in the Southern Ocean southwest of Australia during the last one million years. In Suggate, R. P., and Cresswell, M. M. (Eds.), Quaternary Studies: Wellington (The Roy. Soc. N.Z.), pp. 297-309.

Vincent, E., Killingley, J. S., and Berger, W. H., 1981. Stable isotope composition of benthic foraminifera from the equatorial Pacific. Nature, 289:639-643.

Volat, J.-L., Pastouret, L., and Vergnaud-Grassini, C., 1980. Dissolution and carbonate fluctuations in Pleistocene deep-sea cores: a review. Mar. Geol., 34:1-28.

Williams, D. F., Moore, W. S., and Fillon, R. H., 1981. Role of glacial Arctic Ocean ice sheets in Pleistocene oxygen isotope and sea level records. Earth Planet. Sci. Lett., 56:157-166.

Date of Initial Receipt: 11 June 1984 Date of Acceptance: 29 October 1984 